\title{
Morpho-anatomical Studies and Evolutionary Interpretations of the Rhizomes of Extant Dennstaedtiaceae
}

Author(s): Ivan Becari-Viana and Pedro Bond Schwartsburd

Source: American Fern Journal, 107(3):105-123.

Published By: The American Fern Society

https://doi.org/10.1640/0002-8444-107.3.105

URL: http://www.bioone.org/doi/full/10.1640/0002-8444-107.3.105

BioOne (www.bioone.org) is a nonprofit, online aggregation of core research in the biological, ecological, and environmental sciences. BioOne provides a sustainable online platform for over 170 journals and books published by nonprofit societies, associations, museums, institutions, and presses.

Your use of this PDF, the BioOne Web site, and all posted and associated content indicates your acceptance of BioOne's Terms of Use, available at www.bioone.org/ page/terms_of_use.

Usage of BioOne content is strictly limited to personal, educational, and noncommercial use. Commercial inquiries or rights and permissions requests should be directed to the individual publisher as copyright holder. 


\title{
Morpho-anatomical Studies and Evolutionary Interpretations of the Rhizomes of Extant Dennstaedtiaceae
}

\author{
IVAN BECARI-VIANA \\ Programa de Pós-Graduação em Botânica, Departamento de Biologia Vegetal, Universidade Federal \\ de Viçosa, Av. Peter H. Rolfs s.n., Viçosa, MG, Brazil, CEP 36570-900 \\ ivanbio2009@gmail.com \\ Pedro Bond Schwartsburd \\ Programa de Pós-Graduação em Botânica, Departamento de Biologia Vegetal, Universidade Federal \\ de Viçosa, Av. Peter H. Rolfs s.n., Viçosa, MG, Brazil, CEP 36570-900 \\ pedro.schw@ufv.br
}

\begin{abstract}
Aвstract.-Dennstaedtiaceae is a monophyletic, extant family of ferns with sub-cosmopolitan distribution and ca. 265 species. Rhizome morphology in the Dennstaedtiaceae is relatively well known, yet its anatomy has been poorly explored. We performed morpho-anatomical studies on 26 taxa from eight genera, mostly from Brazil, Japan, and New Zealand. Among the studied species, the main rhizome type is long-creeping with alternate phyllotaxy and a solenostele s. str. The exception is Blotiella lindeniana, which has ascending rhizomes with radial phyllotaxy and a dictyostele. A polycyclic solenostele was found in Dennstaedtia ("Patania") cornuta, D. ("Patania") dissecta, and two subspecies of Pteridium arachnoideum. Lateral-line aerenchyma characterized Blotiella lindeniana, Histiopteris incisa, Hypolepis spp., Paesia spp., and Pteridium arachnoideum subspp. The position of sclerified parenchyma in the cortex and pith varied among species. Our data enabled us to hypothesize evolutionary patterns of rhizome evolution in extant lineages of the Dennstaedtiaceae. The "Monachosorideae" has retained ancestral conditions: shortcreeping to ascending rhizomes with dictyostele s. str. In the "Hypolepidoideae", two notable changes occurred in Blotiella and Pteridium (in which the solenostele evolved into a polycyclic solenostele). In the "Dennstaedtioideae", one notable change occurred in Dennstaedtia ("Patania"), namely parallel evolution with Pteridium (in which the polycyclic solenostele has also evolved). We present illustrations, morpho-anatomical descriptions, evolutionary inferences based on the available phylogeny, and supporting tools for studying the taxonomy, systematics, phylogeny, and paleontology of the group.
\end{abstract}

KEY WorDs.—ancient ferns, bracken fern, amphiphloic siphonostele, solenostele

Dennstaedtiaceae Lotsy is a monophyletic family of extant leptosporangiate ferns containing 10 genera and ca. 265 living species (PPG I, 2016). The family has a subcosmopolitan distribution, primarily due to the widely-distributed bracken ferns, Pteridium Gled ex Scop. (Der et al., 2009; Tryon, 1941).

Although the Cretaceous diversification of the Polypodiales (sensu PPG I, 2016) has been controversial, Schneider, Schmidt, and Heinrichs (2016) just recently described a leaf from the mid-Cretaceous, Krameropteris resinatus H.Schneid et al., with an undeniable cathetogyrate sporangium, and the authors ascribed it to the Dennstaedtiaceae. This discovery supports the molecular clock estimates for the origin of the family, of ca. 115 mya (Schneider et al., 2004). Three other fossil genera are also ascribed to the 
family: Microlepiopsis Sebert \& Rothwell, also from the Cretaceous; Dennastra McIver \& Basinger; and Dennstaedtiopsis Arnold \& Daugherty (Collinson, 2001; Fossilworks, 2016; Sebert and Rothwell, 2003; Shi, Schopf, and Kudryavtsev, 2013).

As currently defined (Smith et al., 2008; PPG I, 2016), most extant genera of Dennstaedtiaceae are probably monophyletic, except possibly for Hypolepis Bernh. (Brownsey, 1983) and for the clearly paraphyletic Dennstaedtia Bernh. (Perrie, Shepherd, and Brownsey, 2015; Schneider, Schmidt, and Heinrichs 2016; Schuettpelz and Pryer, 2007).

Stems in Dennstaedtiaceae are generally long-creeping rhizomes, and both their external morphology and internal anatomy are fairly well known (Bower, 1926; Gruber, 1981; Gwynne-Vaughan, 1903; Kaur, 1971; Keating, 1968; Kramer, 1990; Nair and Sem, 1974; Navarrete and Øllgaard, 2000; Ogura 1972; Schwartsburd and Prado, 2015; Troop and Mickel, 1968; Tryon and Tryon, 1982; Watt, 1940). However, research focusing on rhizome anatomy in the family has addressed only a few genera and species, and some features of the species, such as their lateral-line aerenchyma, have been poorly analyzed.

The anatomy of stems, especially of their vascular system, is considered to be a conserved character, as these organs are affected by only few environmental influences and have undergone few evolutionary modifications (Srivastava and Chandra, 2009). It has been hypothesized that the diversity of primary vascular systems was established early in the evolution of vascular plants (Beck, Schmid, and Rothwell, 1982). Studies on stem morpho-anatomy may yield important information on the relationships between extinct and extant taxa (Cantrill, 1997; Matsumoto et al., 2006) as well as on the evolution of monophyletic lineages (Ebihara, 2007; Pryer, Smith, and Skog, 1995; Roux and Wyk, 2000; Smith, 1995).

In this paper, we provide an initial database on morphological features combined with anatomical characteristics of selected species from some extant Dennstaedtiaceae genera, in order to contribute complementary morphological data for circumscription of genera and to infer the evolutionary history of rhizomes in the family.

\section{Material AND Methods}

We sampled 26 taxa (23 species, two subspecies, and one variety) belonging to eight genera of the Dennstaedtiaceae (sensu PPG I, 2016), mostly from Brazil, Japan, and New Zealand (Appendix 1). Sixty two specimens were analyzed, of which 35 were freshly collected and 27 were obtained from exsiccates (from herbaria CRH, TNS, and VIC). Rhizome external morphology was analyzed by naked eye and under a stereo microscope (model SMZ 068, Motic, China).

For the anatomical analysis, fragments were sampled from the internode mid

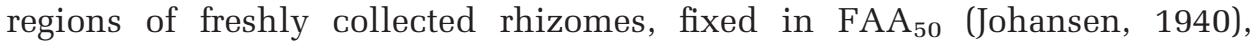
dehydrated in an ethanol series, and embedded in methacrylate resin (Leica Historesin, Germany). Transversal and longitudinal sections 5-7 $\mu \mathrm{m}$ thick were obtained using an advance rotary microtome (model Spencer 820, 
American Optical Corporation, USA). Sections were stained with toluidine blue, pH 7.2 (O’Brian and McCully, 1981), and mounted in synthetic resin (Permount-Fischer). For samples from herbarium materials, rhizome fragments were first rehydrated (Smith and Smith, 1942) and then subjected to the method described above. We also performed a Phloroglucinol-HCl test for lignin (Johansen, 1940).

Tracheal elements were isolated through maceration and then identified. Rhizome fragments were fixed in Jeffrey solution (Johansen, 1940) for ca. $20 \mathrm{~h}$, washed with distilled water and $50 \%$ ethanol, and stained with $1 \%$ safranin in $50 \%$ ethanol for five h. Samples were then washed in $30 \%$ ethanol and mounted on temporary microscopic glass slides. Samples were documented and photographed using a photomicroscope (model AX70TRF, Olympus Optical, Japan) coupled with a digital camera (AxioCam HR3, Zeiss, Germany).

Classification of the vascular system followed Schmid (1982). Our evolutionary interpretations were based on the available phylogeny of the Dennstaedtiaceae, which was constructed using $r b c L$ sequences (Perrie, Shepherd, and Brownsey, 2015; and Schneider, Schmidt, and Heinrichs, 2016), excluding Saccoloma species from the former study. Sequences of Saccoloma spp. (analyzed by Wolf, 1995), which nested within Dennstaedtiaceae, were later found to be contaminated (Wolf, pers. comm.; see also PPG I, 2016). In the phylograms of Perrie, Shepherd, and Brownsey (2015) and Schneider Schmidt, and Heinrichs (2016), we inserted the species we analyzed, which did not have available rbcL sequences in GenBank (Fig. 1). Our insertions, while speculative (dotted lines), were based on morphological criteria and unpublished trnL-trnF sequences of Hypolepis rugosula subsp. pradoana Schwartsb. and $H$. stolonifera Fée var. stolonifera, which were compared with other Hypolepis spp. (Schwartsburd and Perrie, unpubl. data). To avoid bias, we inserted most species in polytomies. A dual hypothesis was elaborated for Dennstaedtia globulifera (Poir.) Hieron. (indicated by an asterisk).

We named the three main clades of Dennstaedtiaceae (Perrie, Shepherd, and Brownsey, 2015) as: "Monachosoroideae" (containing only Monachosorum Kunze), "Hypolepidoideae" (cont. Paesia A.St.-Hil., Histiopteris J.Agardh, Blotiella R.M.Tryon, Hypolepis Bernh., and Pteridium), and "Dennstaedtioideae" (cont. paraphyletic Dennstaedtia Bernh., Oenotrichia Copel., Leptolepia Kuhn, and Microlepia C.Presl). We also put alternative generic names for some Dennstaedtia species in brackets, similar to Schneider, Schmidt, and Heinrichs (2016). One sensitive difference from Schneider, Schmidt, and Heinrichs (2016) regards the placement of "Patania". The type of Patania C.Presl is P. obtusifolia ( $=D$. obtusifolia), which forms a species complex with D. dissecta (Sw.) T. Moore and D. cornuta (Kaulf.) Mett. Thus, we named this clade "Patania"; and not D. scabra, as Schneider, Schmidt, and Heinrichs (2016) did. We polarized our tree using some basal Pteridaceae genera, such as Llavea Lag. and Cryptogramma R. Br. (e.g., Pabón-Mora and González, 2016). That baseline information was used to describe the rhizome of our hypothetical ancestor of the Dennstaedtiaceae. 


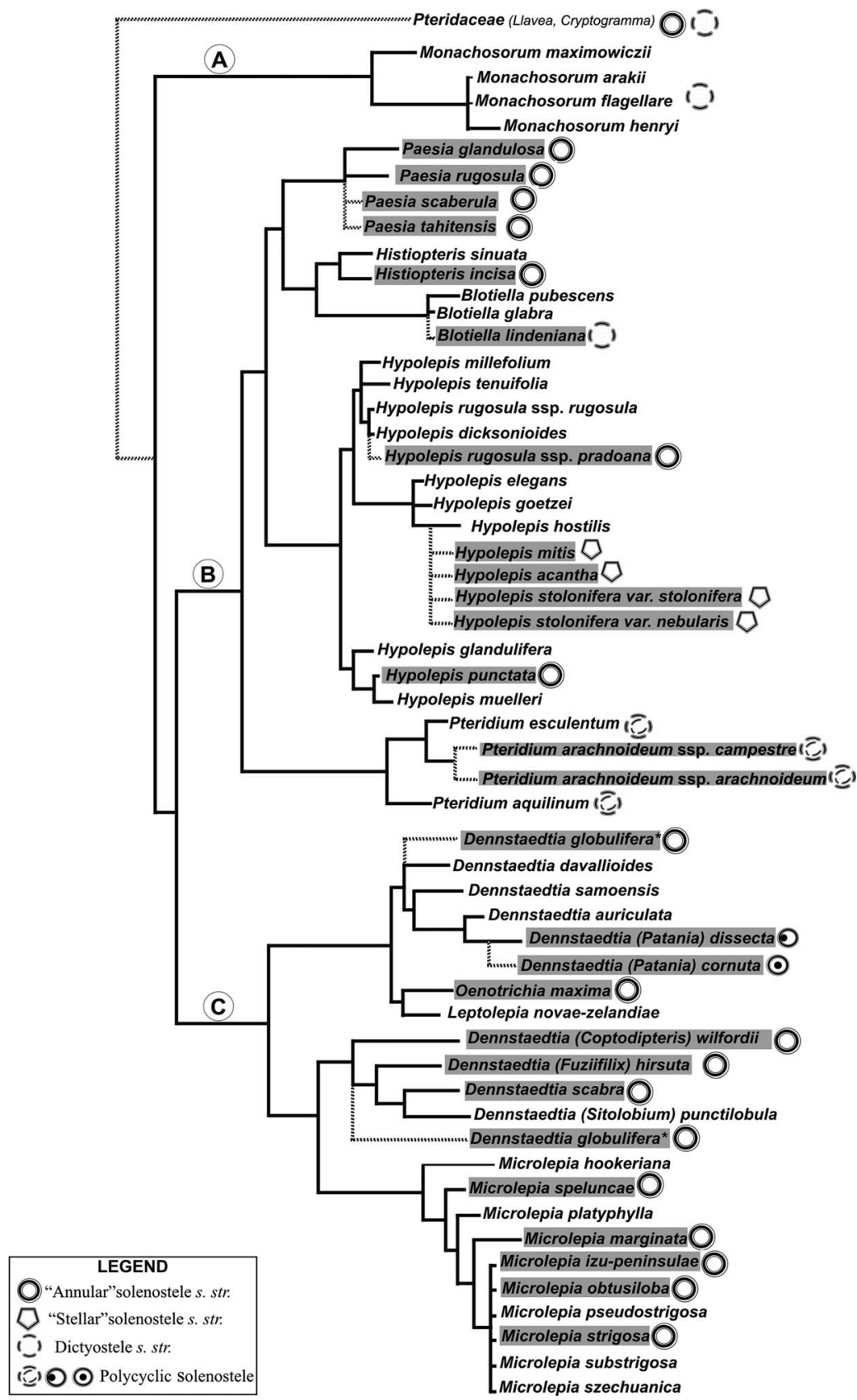

FIG. 1. Phylogram of Dennstaedtiaceae, according to Perrie, Shepherd, and Brownsey (2015) and Schneider, Schmidt, and Heinrichs (2016). Species sampled in our study are highlighted in gray. Dotted lines show tentative positioning of species not sampled in the original phylogenies. Asterisks indicate alternate hypotheses of the relationships in Dennstaedtia globulifera. 
RESULTS

Rhizome morphology is relatively homogeneous among the studied species. Among the species studied, the main rhizome type was the creeping rhizome (Fig. 2C, 2D, 3A, 3D, 3F, 4A, 4B, 4D, 4F, 4G) with alternate phyllotaxy (e.g., Fig. $4 \mathrm{G}$ ), except in Blotiella lindeniana (Fig. 2A), which has ascending rhizomes with radiate phyllotaxy. With a few exceptions of either glabrous or glabrescent rhizomes (Dennstaedtia (Patania) cornuta), most species are furnished with catenate hairs (Figs. 3E, 4C, E, 7H). Histiopteris incisa has also comose proto-scales (Figs. 3B, 7G). Epipetiolar buds (e.g., Fig. 3F), secondary roots (e.g., Fig. 3F), and catenate hairs are found at the base of petioles in most species.

All species have an uniseriate epidermis. The lateral-line aerenchyma is present in Blotiella lindeniana (Figs. 2B, 8C, E), Histiopteris incisa (Figs. 3A, C), Hypolepis spp. (Figs. 3G, 8D, F), Paesia spp. (Figs. 3E, 8B), and Pteridium arachnoideum subspp. (Figs.2E - arrows, 8A). Lines of aerenchyma run laterally on rhizomes and have stomata on their surface (Figs. 8D, E). The aerenchyma below the epidermis is characterized by conspicuous intercellular gaps and by intercellular protuberances (IP) of cell walls (Fig. 8F). Blotiella lindeniana, Paesia spp., and Pteridium arachnoideum subspp. have "necklike" extensions from the inner cortex to the aerenchyma (Figs. 8A-C). Neither Histiopteris incisa nor Hypolepis spp. have such "neck-like" extensions (e.g., Fig. 8D).

The location of sclerified parenchyma layers in the cortex varies among species. This tissue is composed by slightly longer cells with thick cell walls, but without lignin deposit (thus not composing a true sclerenchyma). Those layers may be located in the outer, medium, and/or inner cortex. Hypolepis spp., Histiopteris incisa, and Oenotrichia maxima have sclerified parenchyma in the inner cortex (next to the endodermis) (e.g., Fig. 7E). On the other hand, the inner cortex of Blotiella lindeniana, Paesia spp., Dennstaedtia spp., Microlepia spp., and Pteridium arachnoideum subspp. has unmodified parenchyma (e.g., Fig. 7F).

The vascular systems of all studied species are classified into the major group of amphiphloic siphonostele sensu Schmid (1982). In this group, steles are enclosed by both an inner and outer endodermis. In all species we studied, the endodermis is formed by tabular cells without lignin deposit. The pericycle below it is formed by two layers of isodiametric cells (e.g., Fig. 7A). We found three types of steles (sensu Schmid 1982): 1. solenostele s. str., 2. polycyclic solenostele, and 3. dictyostele s. str.

Solenostele s. str. is, by far, the most common stele type in the Dennstaedtiaceae (Figs. 5A-C, E, 6C-H). This stele type was found in Dennstaedtia globulifera (Fig. 6D), D. (Fuziifilix) hirsuta (Fig. 6E), D. scabra, D. (Coptodipteris) wilfordii (Fig. 6C), Histiopteris incisa (Fig. 5C), Hypolepis acantha (Fig. 5A), Hyp. mitis, Hyp. punctata (Fig. 5B), Hyp. rugosula subsp. pradoana, Hyp. stolonifera var. stolonifera, Hyp. stolonifera var. nebularis, Microlepia izu-peninsulae, M. marginata, M. obtusiloba (Fig. 6G), M. 

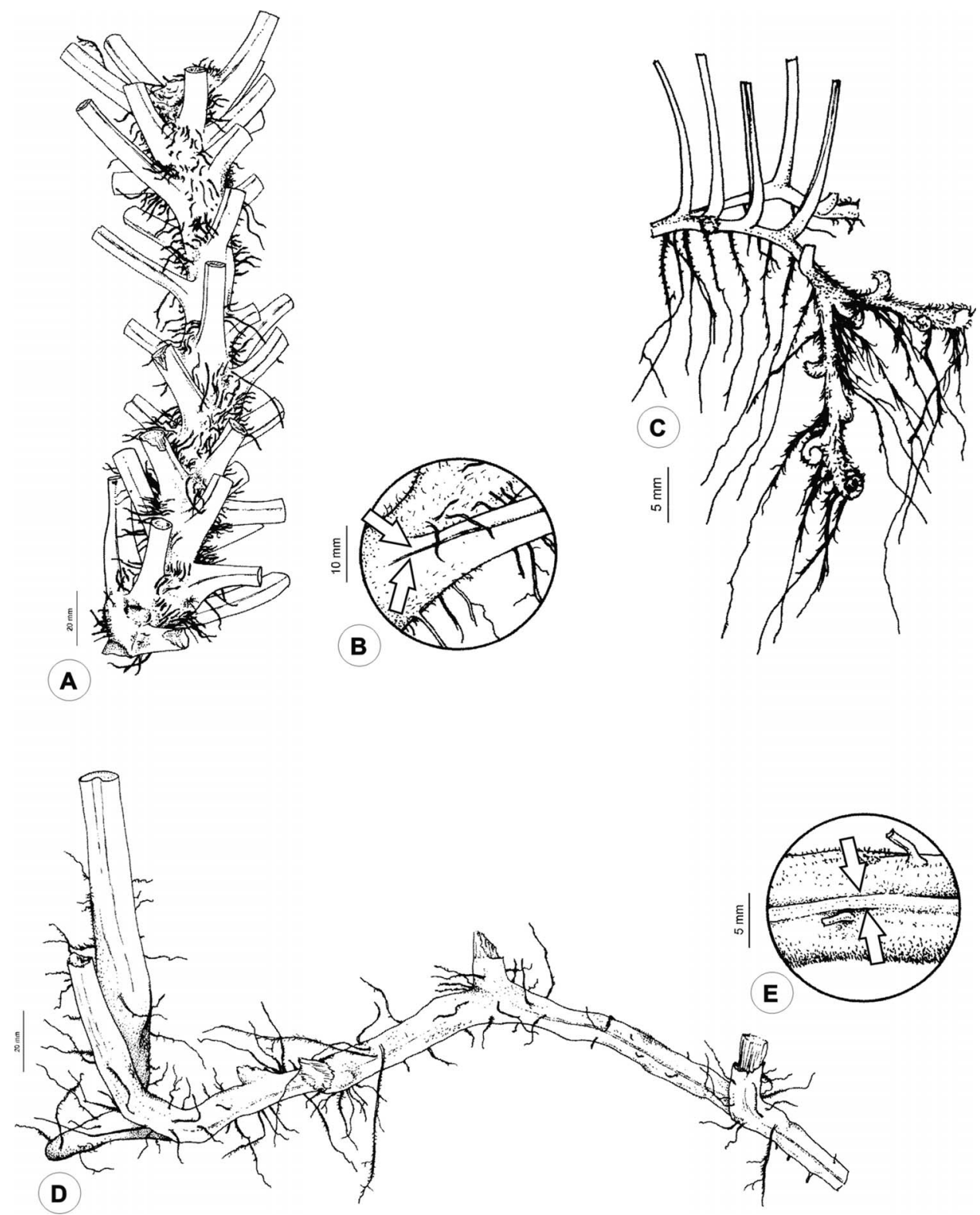

FIG. 2. Habit and rhizome morphology in the Dennstaedtiaceae. A, B. Blotiella lindeniana. A. Ascending rhizome. B. Arrows indicate the lateral-line aerenchyma, which extends from the rhizome to the petiole. C. Creeping rhizome of Dennstaedtia (Coptodipteris) wilfordii. D, E. Pteridium arachnoideum subsp. campestre. D. Creeping rhizome. E. Arrows indicate the lateralline aerenchyma. 

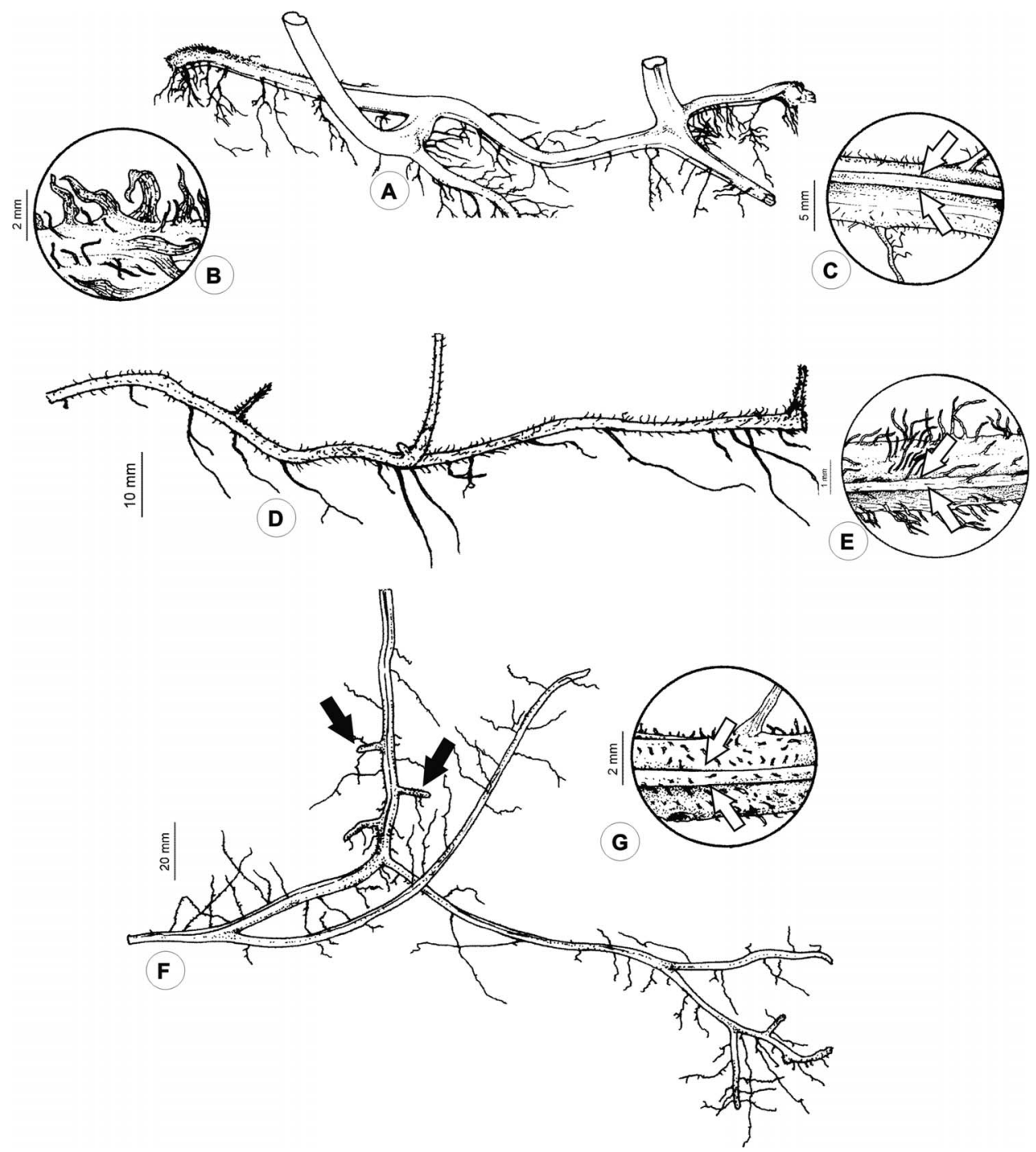

FIG. 3. Habit and rhizome morphology in the Dennstaedtiaceae. A-C. Histiopteris incisa. A. Creeping rhizome. B. Detail of comose proto-scales and hairs. C. Arrows indicate the lateral-line aerenchyma. D, E. Paesia glandulosa. D. Creeping rhizome. E. Arrows indicate the lateral-line aerenchyma. F, G. Hypolepis stolonifera var. nebularis. F. Creeping rhizome (Arrows indicate epipetiolar buds). G. Arrows indicate the lateral-line aerenchyma.

speluncae (Fig. 6H), M. strigosa, Oenotrichia maxima (Fig. 6F), Paesia glandulosa (Fig. 5E), P. rugosula, P. scaberula, and P. tahitensis. All these species have annular solenosteles, except for Hyp. acantha, Hyp. mitis, Hyp. stolonifera var. stolonifera, and Hyp. stolonifera var. nebularis, which have stellar solenosteles with well-defined protoxylem poles (e.g., Fig. 5A). 


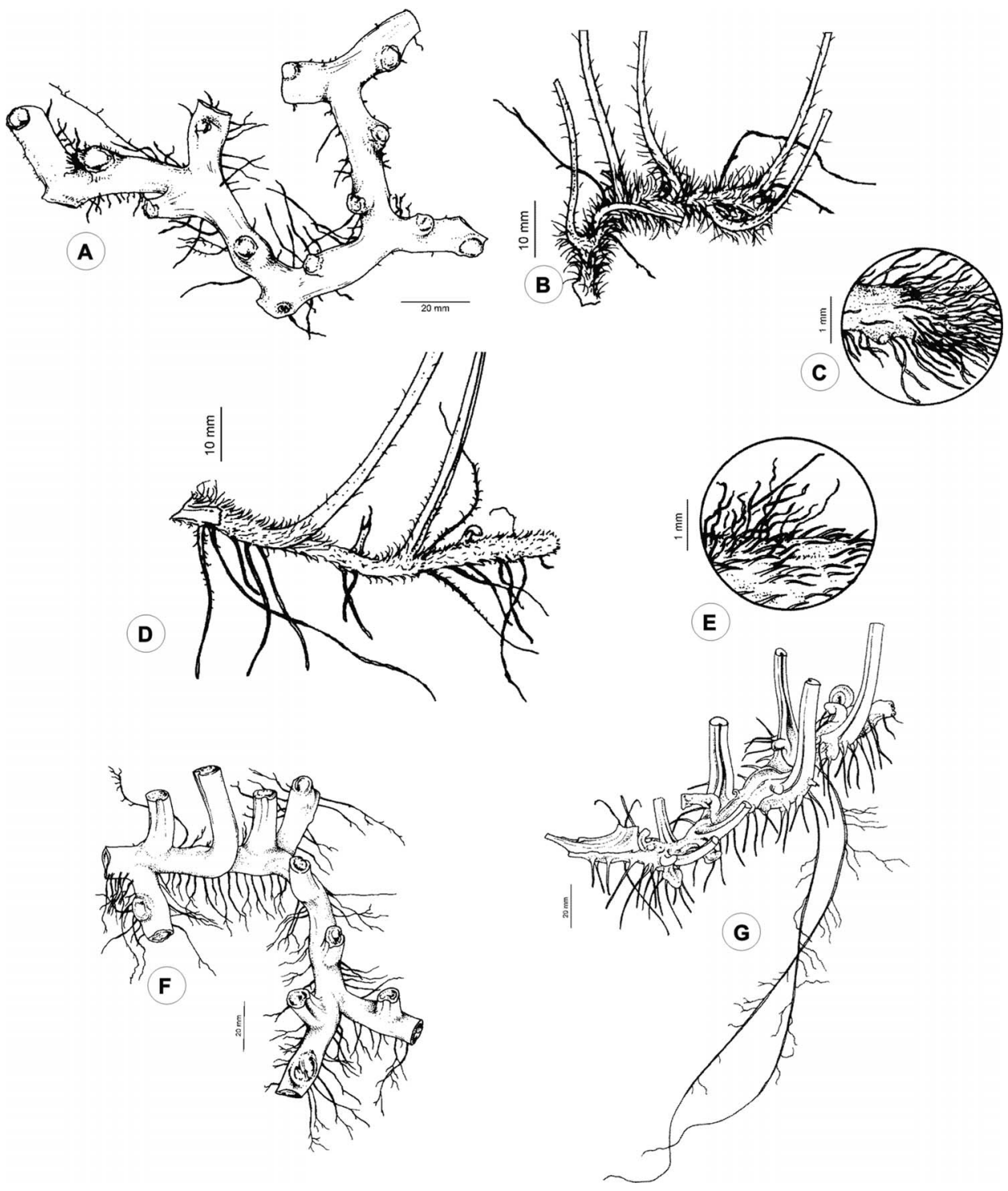

FIG. 4. Habit and rhizome morphology in the Dennstaedtiaceae. A. Creeping rhizome in Dennstaedtia globulifera. B, C. Dennstaedtia (Fuziifilix) hirsuta. B. Creeping rhizome. C. Detail of catenate hairs. D, E. Microlepia marginata. D. Creeping rhizome. E. Detail of catenate hairs. F. Creeping rhizome in Microlepia speluncae. G. Short-creeping rhizome in Dennstaedtia (Patania) cornuta.

The two other stele types are rare in the family. Blotiella lindeniana has a dictyostele s. str. (Fig. 5D), while Dennstaedtia ("Patania") dissecta, D. ("Patania") cornuta, Pteridium arachnoideum subsp. arachnoiudem, and $P$. arachnoideum subsp. campestre have a polycyclic solenostele (Figs. 5F, 6A- 


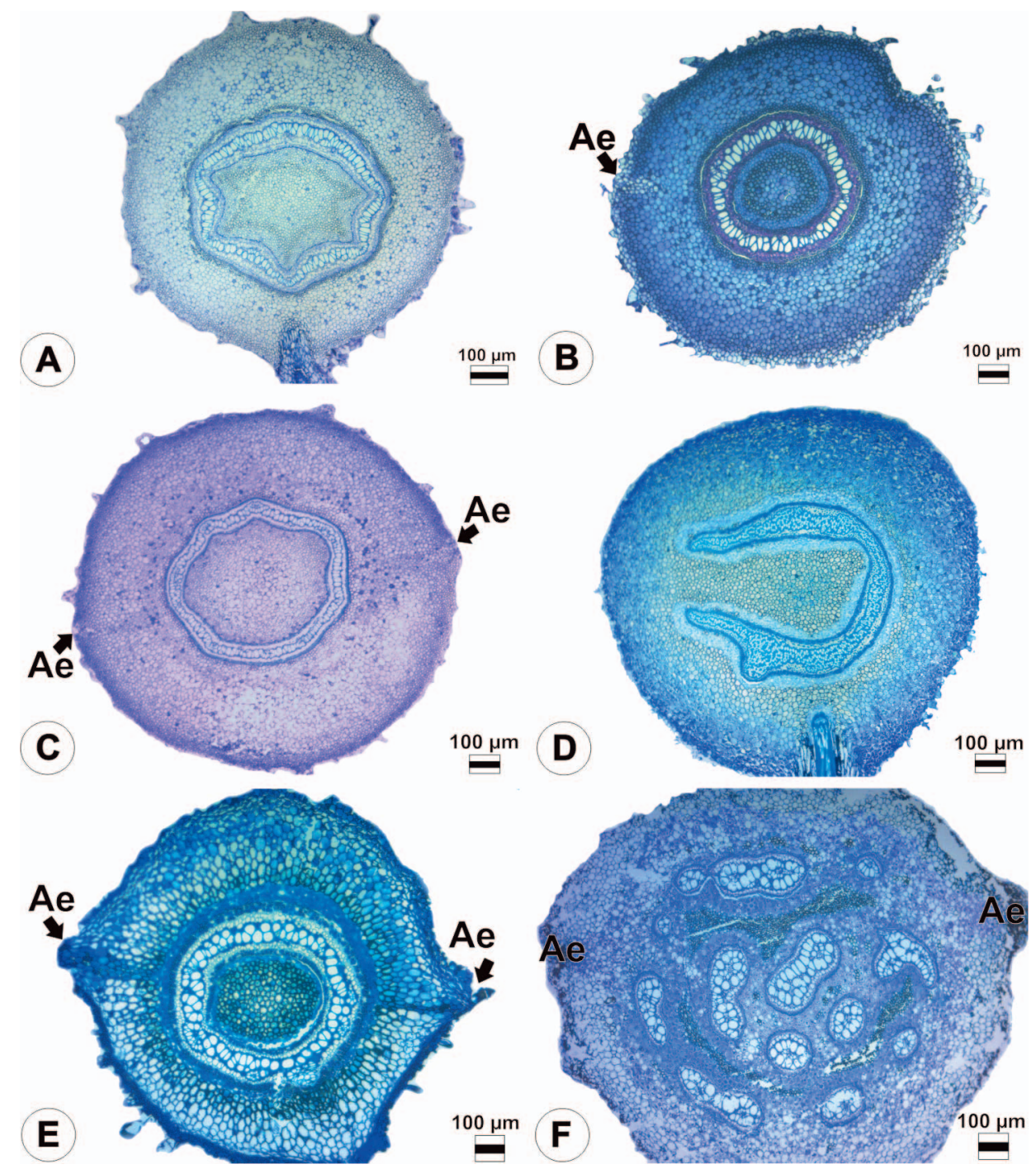

FIG. 5. Anatomical overview of rhizomes in the Dennstaedtiaceae (in cross section). A. Hypolepis acantha. B. Hypolepis punctata. C. Histiopteris incisa. D. Blotiella lindeniana. E. Paesia glandulosa. F. Pteridium arachnoideum subsp. campestre. "Ae" = lateral-line aerenchyma.

B). The polycyclic solenostele differed among these four taxa. In D. dissecta, there is a vascular protuberance inward the annular solenostele (Fig. 6B). In $D$. cornuta, there are either two concentric annular solenosteles (Fig. 6A), or occasionally the inner solenostele may have no pith, thus resembling a protostele. In Pteridium arachnoideum subspp., there are two concentric rows of meristeles (Figs. 5F, 7B). 


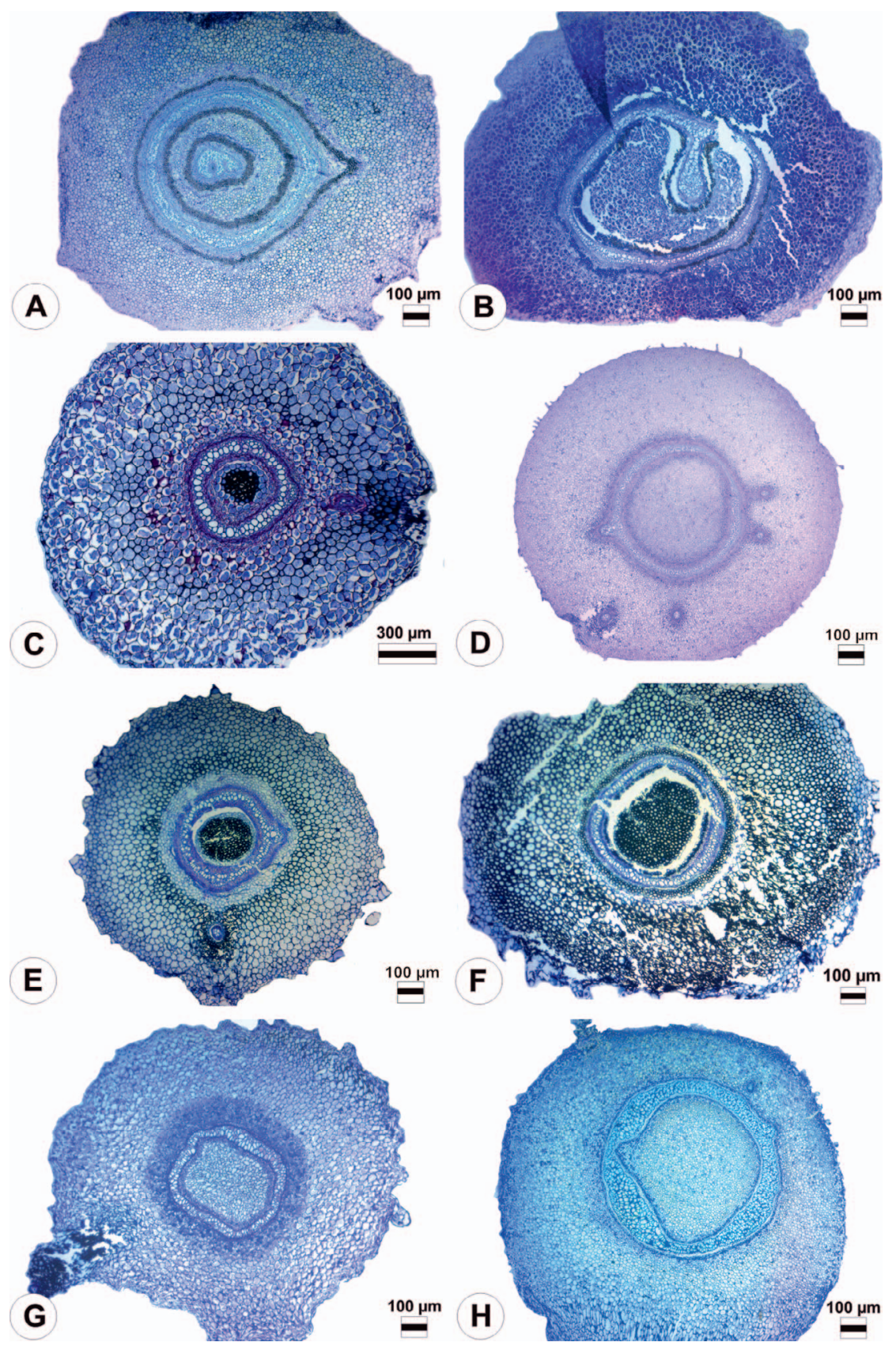

FIG. 6. Anatomical overview of rhizomes in the Dennstaedtiaceae (in cross section). A. Dennstaedtia (Patania) cornuta. B. Dennstaedtia (Patania) dissecta. C. Dennstaedtia (Coptodipteris) wilfordii. D. Dennstaedtia globulifera. E. Dennstaedtia (Fuziifilix) hirsuta. F. Oenotrichia maxima. G. Microlepia obtusiloba. H. Micropelia speluncae. 

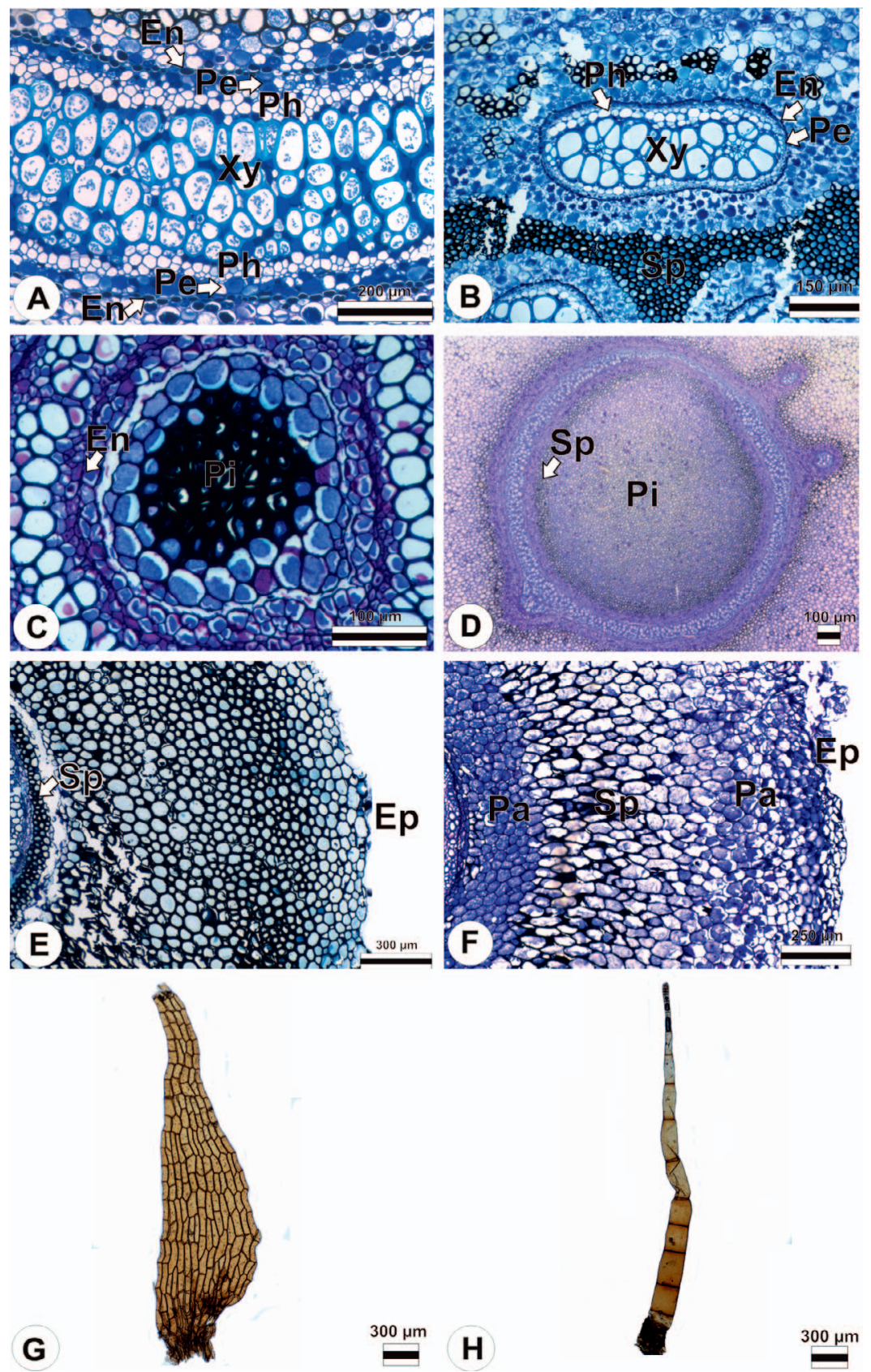

FIG. 7. Anatomical details of rhizomes in the Dennstaedtiaceae (A-F in cross section). A. Vascular bundle with inner and outer endodermis in Microlepia speluncae. B. Meristele of Pteridium arachnoideum subsp. campestre. C. Inner pith with sclerified parenchyma in Dennstaedtia (Coptodipteris) wilfordii. D. Pith with only its outer layer having a sclerified parenchyma in Dennstaedtia globulifera. E. Cortex of Oenotrichia maxima. F. Cortex of Microlepia marginata. G. Comose proto-scales of Histiopteris incisa. H. Catenate hair of Hypolepis acantha. "En"= endodermis; "Ep"= epidermis; "Pa"= non-sclerified parenchyma; "Pe"= pericycle; "Ph"= phloem; "Pi"= pith; "Sp"= Sclerified parenchyma; $\mathrm{Xy}=$ xylem. 

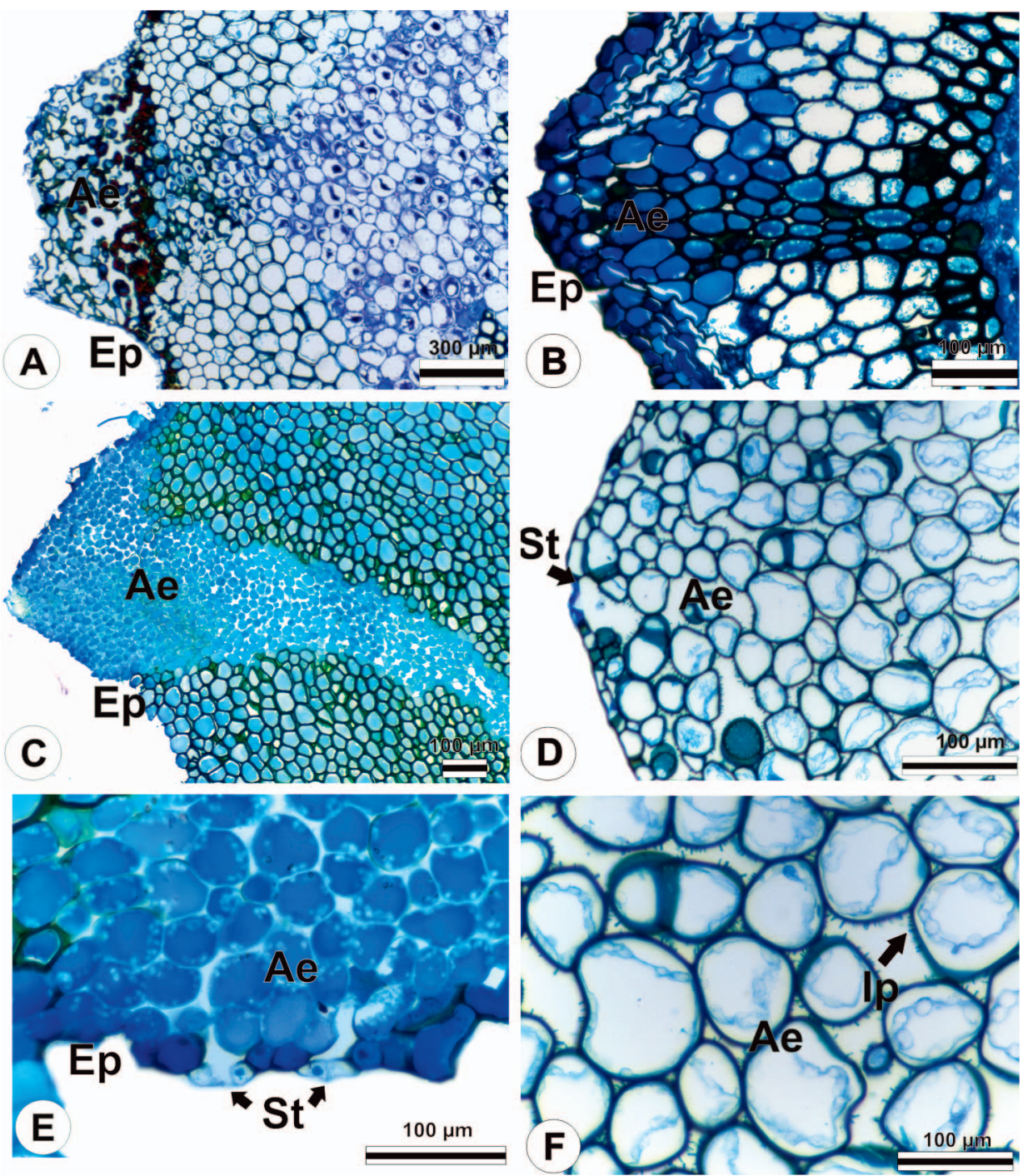

FIG. 8. Lateral-line aerenchyma in rhizomes of the Dennstaedtiaceae (in cross section). A. Pteridium arachnoideum subsp. campestre. B. Paesia glandulosa. C. Blotiella lindeniana. D. Hypolepis acantha. E. Detail of stomata on the epidermis of Blotiella lindeniana. F. Detail of intercellular protuberances in Hypolepis acantha. "Ae"= lateral-line aerenchyma; "Ep"= epidermis; "Ip"= inter-cellular protuberances; "St"= stomata.

All species have only scalariform tracheids as conducting cells in the xylem, except for Pteridium arachnoideum subspp., which also have vessel elements. Phloem in the species is formed by sieve cells.

Pith composition also varies among species. Some of them have sclerified parenchyma occupying almost the entire pith, while others have sclerified 
parenchyma only in the outermost pith layers (i.e., those next to the endodermis). Blotiella lindeniana, Dennstaedtia hirsuta, D. scabra, D. wilfordii, Microlepia marginata, M. izu-peninsulae, M. obtusiloba, M. strigosa, Oenotrichia maxima, and Paesia spp. have sclerified parenchyma occupying almost the entire pith (e.g., Fig. 7C). On the other hand, in D. globulifera, Histiopteris incisa, Hypolepis spp., and M. speluncae only the outermost layers are occupied by sclerified parenchyma (e.g., Fig. 7D).

TENTATIVE KEY TO GENERA OF DENNSTAEDTIACEAE BASED ON THE MORPHO-ANATOMY OF THE STUDIED SPECIES (SOME DENNSTAEDTIA AND MicROLEPIA SPECIES CANNOT BE PRECISELY DISTINGUISHED):

1. Rhizomes solenostelic s. str.

2. Rhizomes bearing catenate hairs and comose scales ........... Histiopteris

2. Rhizomes bearing catenate hairs only

3. Rhizomes with stellar solenostele s. str. . . . . . . . . . . . . Hypolepis (in part)

3. Rhizomes with annular solenostele s. str.

4. Lateral-line aerenchyma present

5. Pith mostly sclerified $\ldots \ldots \ldots \ldots \ldots \ldots \ldots \ldots \ldots \ldots \ldots$

5. Pith with only the peripheral region sclerified ....... Hypolepis (in part)

4. Lateral-line aerenchyma absent

6. Inner cortex sclerified adjacent to the outer endodermis . . . . . Oenotrichia

6. Inner cortex not sclerified

7. Pith with only the peripheral region sclerified $\ldots \ldots \ldots \ldots \ldots \ldots$ ........ Dennstaedtia (D. globulifera) and Microlepia (M. speluncae)

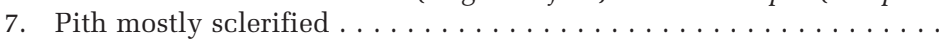
............. Dennstaedtia (D. scabra, D. hirsuta, D. wilfordii) and Microlepia (M. marginata, M. izu-peninsulae, M. obtusiloba, M. strigosa)

1. Rhizomes with dictyostele $s$. str. or polycyclic solenostele

8. Rhizomes ascending, with dictyostele . . . . . . . . . . . . . . . Blotiella

8. Rhizomes medium- to long-creeping, with polycyclic solenostele

9. Rhizomes long-creeping; polycyclic solenostele subdivided into meristeles. . . . .

$\ldots \ldots \ldots \ldots \ldots \ldots \ldots \ldots \ldots \ldots \ldots \ldots \ldots \ldots \ldots$ Pteridium

9. Rhizomes medium-creeping; polycyclic solenostele not subdivided into meristeles ......................... Dennstaedtia (Patania)

\section{DisCUSSION}

Evolutionary interpretations.-Based on the outgroup (e.g., Llavea, Cryptogramma), we established a hypothesis on the rhizome of the family ancestor (Fig. 1). This hypothetical ancestor had a short-creeping to ascending rhizome, with dorsiventral symmetry, short internodes, either a solenostele $s$. str. or a transitional dictyostele s. str., and indumentum formed by scales. The first divergent lineage ("Monachosorideae", Fig. 1 - clade A) from the ancestor retained its conserved features, which is similar to the basal Pteridaceae (Nair and Sem, 1974; Kramer, 1990). The exception is the indumentum, which consisted of hairs.

In the other lineage (a large clade containing "Hypolepidoideae" and "Denstaedtioideae", Fig 1 - clades B and C, respectively), a higher morpho- 
anatomical diversification occurred in rhizomes. In this large clade, the main rhizome type is long-creeping with extended internodes, solenostele s. str., and indumentum formed also by hairs.

Within the "Hypolepidoideae" (Fig. 1 - clade B), the long-creeping rhizome with solenostele s. str. is maintained in Paesia (Figs. 3D, 5E), Histiopteris (Figs. 3A, 5C), and Hypolepis (Figs. 3F, 5A, B), but two notable changes occurred within this clade. In Blotiella, the rhizome became truly ascending with radial symmetry, but also with a dictyostele $s$. str., similar to the one of the ancestor (Figs. 2A, 5D). The other change occurred in Pteridium. The rhizome remained long-creeping, but the vascular system evolved into a polycyclic solenostele (Figs. 2D, 5F). The polycyclic solenostele of Pteridium is considered to be an advanced stage of the dictyostele s. str., having probably derived from two concentric rings of dictyostele (Ogura, 1972). Pteridium has also vessel elements, which is a unique feature in the Dennstaedtiaceae. From the points of view of survival and colonizing success, the new features in Pteridium were extremely advantageous, in light of its current distribution and biomass, when compared with those of other Dennstaedtiaceae genera (e.g., Der et al., 2009; Schwartsburd, Moraes, and Lopes-Mattos, 2014; Tryon, 1941).

The presence of comose proto-scales in rhizomes of Histiopteris (Figs. 3B, 7G) may be considered the result of reverse evolution. Within Hypolepis, there was also a slight change in shape of the solenostele s. str. Some species retained the annular solenostele (Fig. 5B), while others evolved the stellar solenostele with protoxylem poles (Fig. 5A).

In the "Dennstaedtioideae" clade (Fig. 1 - clade C), the long-creeping rhizomes with solenostele $s$. str. also remained as the main rhizome type, being present in Microlepia (Figs. 4D, F, 6G, H), Oenotrichia (Fig. 6F), and most species of Dennstaedtia (Figs. 4A, B, 6C-E), including "Coptodipteris" and "Fuziifilix". Within "Dennstaedtioideae", one notable change occurred. The rhizomes of Dennstaedtia "Patania" became medium-creeping, and the vascular system evolved from solenostele $s$. str. into a polycyclic solenostele (Figs. 4G, 6A, B). The polycyclic solenostele represents a parallel evolution between Dennstaedtia "Patania" ("Dennstaedtioideae" clade) and Pteridium ("Hypolepidoideae" clade). The shape of the polycyclic solenostele in D. (Patania) dissecta (Fig. 6B) is probably an intermediary condition between the solenostele s. str. and the shape found in D. (Patania) cornuta (Fig. 6A).

The three fossil genera with rhizomes currently ascribed to the Dennstaedtiaceae (Dennastra, Dennstaedtiopsis, and Microlepiopsis) are similar to the extant genera of the family, especially in their vascular system. This also indicates the conservation of the main characters along lineages of the Dennstaedtiaceae. The notable aerenchyma in Dennstaedtiopsis aerenchymata (Shi, Schopf, and Kudryavtsev, 2013) may either be only an isolated acclimatization to marshy places or represent a feature from another lineage of Dennstaedtiaceae that is now extinct. 
Contributions to taxonomy and systematics.-Some variation in rhizomes of the Dennstaedtiaceae may be valuable to the taxonomy and systematics of the family. Differential distribution of the sclerified parenchyma in the pith and cortex (Figs. 7C-F) is an important feature to distinguish Dennstaedtia s.l., Hypolepis, Histiopteris, and Paesia. This tissue type has taxonomic value in other fern families, and is responsible for protection and support of the stele (Ogura, 1972).

The lateral-line aerenchyma (Fig. 8) present in Blotiella, Hypolepis, Histiopteris, Paesia, and Pteridium also has taxonomic value. Such a lateral line has been described in many fern families, but primarily in petioles and not in rhizomes (Davies, 1991; Schwartsburd and Prado, 2015). Lateral-line aerenchyma has been reported in Histiopteris incisa and P. aquilinum (Ogura, 1972, as "pneumatic stripes"), and to a few species of Dennstaedtia and Hypolepis (Heidelberg, 1976). The occurrence of stomata and IP in the lateral-line aerenchyma has been reported by Barton, Overall, and Thomson (2015) in P. aquilinum subsp. aquilinum, P. aquilinum subsp. wightianum, and P. esculentum subsp. esculentum. On the other hand, IP had never been reported from any other Dennstaedtiaceae genus. These structures seem to be intimately related to the aerenchyma in the family.

Microlepia and Dennstaedtia s.l. (except "Patania") have indistinguishable rhizome anatomies (Figs. 6C-E, G, H). Dennstaedtia was demonstrated to be paraphyletic by Perrie, Shepherd, and Brownsey (2015) and Schneider, Schmidt, and Heinrichs (2016), with most of its species nesting within Microlepia and other species nesting within another clade. Dennstaedtia will probably be split into two to several smaller genera so that a monophyletic classification may be established. Our anatomical data agree with the phylogenetic conclusions. Probably, "Patania" will be resurrected as a valid genus, and most diagnostic features will be based on rhizomes (mediumcreeping, polycyclic solenostele, etc.).

Lastly, this work also aimed to provide the first database on rhizomes of the Dennstaedtiaceae. We hope our data will be useful for paleontologists to compare extinct and extant genera and help them classify fossil specimens into extant genera.

\section{ACKNOWLEDGMENTS}

We thank CAPES (Coordenação de Aperfeiçoamento de Pessoal de Nível Superior) for granting a fund to the senior author; Programa de Pós-Graduação em Botânica of Universidade Federal de Viçosa for granting us financial support for field expeditions; herbaria TNS and CRH for lending and donating voucher specimens; Valéria Fernandes Ferreira and Luana de Jesus Pereira for providing us with support in anatomical procedures; Aristea A. Azevedo, the editor, and three anonymous reviewers for their critical review on the early version of the manuscript.

\section{Literature Cited}

Barton, D. A., R. L. Overall and J. A. Thomson. 2015. Structure and development of the lateral-line aerenchyma in bracken ferns (Pteridium: Dennstaedtiaceae). International Journal of Plant Sciences 176:662-669. 
Beck, C. B., R. Schmid, and G. W. RothweLL. 1982. Stelar morphology of the primary vascular system of seed plants. Botanical Review 48:691-815.

Bower, F. O. 1926. The Ferns (Filicales). Vol. 2. The Eusporangiate and other relatively primitive ferns. Cambridge University Press, London.

Brownsey, P. J. 1983. Polyploidy and aneuploidy in Hypolepis, and the evolution of the Dennstaedtiales. American Fern Journal 73:97-108.

Cantrill, D. J. 1997. The pteridophyte Ashicaulis livingstonensis (Osmundaceae) from the Upper Cretaceous of Williams Point, Livingston Island, Antarctica. New Zealand Journal of Geology and Geophysics 40:315-323.

Collinson, M. E. 2001. Cainozoic ferns and their distribution. Brittonia 53:173-235.

DAvies, K. L. 1991. A brief comparative survey of aerophore structure within the Filicopsida. Botanical Journal of the Linnean Society 107:115-137.

Der, J. P., J. A. Thomson, J. K. Stratford, and P. G. Wolf. 2009. Global chloroplast phylogeny and biogeography of bracken (Pteridium; Dennstaedtiaceae). American Journal of Botany 96:1041-1049.

Ebihara, A., K. Imatsuki, M. Ito, S. Hennequin, and J-Y. Dubuisson. 2007. A global molecular phylogeny of the fern genus Trichomanes (Hymenophyllaceae) with special reference to stem anatomy. Botanical Journal of the Linnean Society 155:1-27.

Fossilworks. Available from: http://fossilworks.org/. Accessed on $25^{\text {th }}$ April 2017.

Gruber, T. M. 1981. The branching pattern of Hypolepis repens. American Fern Journal 71:41-47.

Gwynne-Vaughan, D. T. 1903. Observations on the anatomy of solenostelic ferns. Annals of Botany 17:689-742.

Heidelberg, W. H. 1976. Sind Farne Kormophyten? Eine Alternative zur Telomtheorie. Plant Systematics Evolution 124:251-277.

Johansen, D. A. 1940. Plant microtechnique. McGraw-Hill Book Company, New York.

Kaur, S. 1971. Contributions to the morphology of Dennstaedtia. Proceedings of the Indian Academy of Sciences, section B, 75: 32-39.

Keating, R. C. 1968. Trends of specialization in the stipe anatomy of Dennstaedtia and related genera. American Fern Journal 58:126-140.

Kramer, K. U. 1990. Dennstaedtiaceae. Pp. 101-144, in K. U. Kramer (ed.), The families and genera of vascular plants: Pteridophytes and Gymnosperms. Springer Verlag, New York.

Matsumoto, M., K. SAiKi, S. Zheng, and W. Yong-Dong. 2006. A new species of Osmundaceous fern rhizome, Ashicaulis macromedullosus sp. nov., from the Middle Jurassic, northern China. Paleontological Research 10:195-205.

NaIr, B. G. and U. SEM. 1974. Morphology and anatomy of Monachosorum subdigitatum (BI.) Kuh with a discussion on its affinities. Annals of Botany 38:749-756.

Navarrete, H., and B. Øllgaard. 2000. The fern genus Dennstaedtia (Dennstaedtiaceae) in Ecuador, new characters, new species and a new combination. Nordic Journal of Botany 20:319-346.

O’Brien, T. P. and M. E. McCully. 1981. The study of plant structure: principles and selected methods. Termarcarphi Pty. Ltda, Melbourne.

OguRA, Y. 1972. Comparative anatomy of vegetative organs of the pteridophytes. Gebrüder Borntraeder, Berlin.

Pabón-Mora, N. and F. González. 2016. Nephopteris out of the clouds: Molecular evidence places the enigmatic N. Maxonii (Pteridaceae) within the Jamesonia clade. Brittonia 68:83-92.

Perrie, L. R., L. D. Shepherd, and P. J. Brownsey. 2015. An expanded phylogeny of the Dennstaedtiaceae ferns: Oenotrichia falls within a non-monophyletic Dennstaedtia, and Saccoloma is polyphyletic. Australian Systematic Botany 28:256-264.

PPG I. 2016. A community-derived classification for extant lycophytes and ferns. Journal of Systematics and Evolution 54: 563-603.

Pryer, K. M., A. R. Smith, and J. E. Skog. 1995. Phylogenetic relationships of extant ferns based on evidence from morphology and $r b c L$ sequences. American Fern Journal 85:205-282.

Roux, J. P. and A. E. V. WYк. 2000. Morphology and anatomy of the rhizome and frond in the African species of Polystichum (Pteropsida: Dryopteridaceae). Bothalia 30:57-68.

Schmid, R. 1982. The terminology and classification of steles: historical perspective and the outlines of a system. The Botanical Review 48:817-931. 
Schneider, H., E. Schuettpelz, K. M. Pryer, R. Cranfill, S. Magallón, and R. Lupia. 2004. Ferns diversified in the shadow of angiosperms. Nature: 428:553-557.

Schneider, H., A. R. Schmidt, and J. Heinrichs. 2016. Burmese amber fossils bridge the gap in the Cretaceous record of polypod ferns. Perspectives in Plant Ecology, Evolution and Systematics 18:70-78.

Schuettpelz, E. and K. M. Pryer. 2007. Fern phylogeny inferred from 400 leptosporangiate species and three plastid genes. Taxon 56:1037-1050.

Schwartsburd, P. B., P. L. R. Moraes, and K. L. B. Lopes-Mattos. 2014. Recognition of two morphotypes in eastern South American brackens (Pteridium - Dennstaedtiaceae - Polypodiopsida). Phytotaxa 170:103-117.

Schwartsburd, P. B. and J. Prado. 2015. A taxonomic revision of the South American species of Hypolepis (Dennstaedtiaceae), part I. American Fern Journal 105:263-313.

Serbet, R. and G. W. Rothwell. 2003. Anatomically preserved ferns from the late cretaceous of western North America: Dennstaedtiaceae. International Journal Plant of Sciences 164:10411051.

Shi, C. S., J.W. Schopf, and A. B. Kudryavtsev. 2013. Characterization of the stem anatomy of the Eocene fern Dennstaedtiopsis aerenchymata (Dennstaedtiaceae) by use of confocal laser scanning microscopy. American Journal of Botany 100:1626-1640.

Sмiтн, A. R. 1995. Non-molecular phylogenetic hypotheses for ferns. American Fern Journal 85:104-122.

Smith, A. R., K. M. Pryer, E. Schuettpelz, P. Korall, H. Schneider, and P. G. Wolf. 2008. Fern classification. Pp. 417-462, in T.A. Ranker and C.H. Haufler (eds.), Biology and evolution of ferns and lycophytes, Cambridge University Press, New York.

Sмiтн, F. H. and E. C. Sмітн. 1942. Anatomy of the inferior ovary of Darbya. American Journal of Botany 29:464-471

SRIvastava, A. and S. Chandra. 2009. Structure and organization of the rhizome vascular system of four Polypodium species. American Fern Journal 99:182-193.

Troop, J. E. and J. T. Mickel. 1968. Petiolar shoots in the Dennstaedtioid and related ferns. American Fern Journal 58:64-70.

Tryon, R. M. 1941. Revision of the genus Pteridium. Rhodora 43:1-31; 37-67.

Tryon, R. M. and A. F. Tryon. 1982. Ferns and allied plants, with special reference to Tropical America. Springer-Verlag, New York.

Watt, A. S. 1940. Contributions to the ecology of bracken (Pteridium aquilinum). I. The rhizome. New Phytologist 39:401-422.

Wolf, P. G. 1995. Phylogenetic analyses of $r b c L$ na nuclear ribosomal RNA gene sequences in Dennstaedtiaceae. American Fern Journal 85:306-327. 
Appendix 1: List of Species and Analyzed Materials

\begin{tabular}{|c|c|c|}
\hline Species & Vouchers & Locality \\
\hline \multirow{3}{*}{$\begin{array}{l}\text { Blotiella lindeniana (Hook.) } \\
\text { R.M.Tryon }\end{array}$} & Schwartsburd \& Becari-Viana 3348 (VIC) & Brazil \\
\hline & Schwartsburd \& Becari-Viana 3401 (VIC) & Brazil \\
\hline & Schwartsburd \& Becari-Viana 3414 (VIC) & Brazil \\
\hline $\begin{array}{l}\text { Dennstaedtia (Patania) dissecta } \\
\text { (Sw.) T.Moore }\end{array}$ & Yañez \& Marquez 104 (VIC) & Argentina \\
\hline \multirow{5}{*}{$\begin{array}{l}\text { Dennstaedtia (Patania) cornuta } \\
\text { (Willd.) T.Moore }\end{array}$} & Schwartsburd \& Becari-Viana 2981 (VIC) & Brazil \\
\hline & Schwartsburd \& Becari-Viana 3070 (VIC) & Brazil \\
\hline & Becari-Viana \& Pereira 10 (VIC) & Brazil \\
\hline & Becari-Viana \& Pereira 11 (VIC) & Brazil \\
\hline & Becari-Viana \& Pereira 12 (VIC) & Brazil \\
\hline \multirow{4}{*}{$\begin{array}{l}\text { Dennstaedtia globulifera (Poir.) } \\
\text { Hieron. }\end{array}$} & Schwartsburd \& Becari-Viana 3069 (VIC) & Brazil \\
\hline & Becari-Viana \& Pereira 06 (VIC) & Brazil \\
\hline & Becari-Viana \& Pereira 07 (VIC) & Brazil \\
\hline & Becari-Viana \& Pereira 08 (VIC) & Brazil \\
\hline \multirow{2}{*}{$\begin{array}{l}\text { Dennstaedtia scabra (Wall.) } \\
\text { T.Moore }\end{array}$} & Yamamoto 2636 (VIC,TNS) & Japan \\
\hline & Yamanaka (VIC-44.535, TNS) & Japan \\
\hline \multirow{2}{*}{$\begin{array}{l}\text { Dennstaedtia (Fuziifilix) hirsuta } \\
\text { (Sw.) Mett. ex Miq. }\end{array}$} & Takesako 4188 (VIC,TNS) & Japan \\
\hline & Shimozono (VIC-44.536, TNS) & Japan \\
\hline \multirow{3}{*}{$\begin{array}{l}\text { Dennstaedtia (Coptodipteris) } \\
\text { wilfordii (T.Moore) Christ. }\end{array}$} & Yuzawa 3494 (TNS) & Japan \\
\hline & Saito (VIC- 44.526, TNS) & Japan \\
\hline & Nagase (VIC-44.538, TNS) & Japan \\
\hline \multirow{4}{*}{$\begin{array}{l}\text { Histiopteris incisa (Thunb.) } \\
\text { J.Sm. }\end{array}$} & Becari-Viana \& Pereira 19 (VIC) & Brazil \\
\hline & Becari-Viana \& Pereira 20 (VIC) & Brazil \\
\hline & Becari-Viana \& Pereira 20 (VIC) & Brazil \\
\hline & Enzat $141(\mathrm{CRH})$ & New Zealand \\
\hline Hypolepis acantha Schwartsb. & Schwartsburd et al. 2264 (VIC) & Brazil \\
\hline \multirow[t]{6}{*}{ Hypolepis mitis Kunze ex Kuhn } & Schwartsburd \& Becari-Viana 3021 (VIC) & Brazil \\
\hline & Schwartsburd \& Becari-Viana 3097 (VIC) & Brazil \\
\hline & Becari-Viana \& Pereira 03 (VIC) & Brazil \\
\hline & Becari-Viana \& Pereira 04 (VIC) & Brazil \\
\hline & Becari-Viana \& Pereira 05 (VIC) & Brazil \\
\hline & Schwartsburd \& Becari-Viana 3316 (VIC) & Brazil \\
\hline $\begin{array}{l}\text { Hypolepis punctata (Thunb.) } \\
\text { Mett. ex Kuhn }\end{array}$ & Tsutsui 5135 (VIC, TNS) & Japan \\
\hline $\begin{array}{l}\text { Hypolepis rugosula subsp. } \\
\text { pradoana Schwartsb. }\end{array}$ & Becari-Viana \& Pereira 01 (VIC) & Brazil \\
\hline \multirow{3}{*}{$\begin{array}{l}\text { Hypolepis stolonifera var. } \\
\text { nebularis Schwartsb. }\end{array}$} & Becari-Viana \& Pereira 13 (VIC) & Brazil \\
\hline & Becari-Viana \& Pereira 15 (VIC) & Brazil \\
\hline & Becari-Viana \& Pereira 14 (VIC) & Brazil \\
\hline $\begin{array}{l}\text { Hypolepis stolonifera Fée var. } \\
\text { stolonifera }\end{array}$ & Labiak et al. 4269 (VIC) & Brasil \\
\hline \multirow{4}{*}{$\begin{array}{l}\text { Microlepia marginata (Panz.) } \\
\text { C.Chr. }\end{array}$} & Iwatsuki \& Kato 79 (CRH) & Japan \\
\hline & Wang et al. 368 (CRH) & China \\
\hline & Haruda 366 (VIC,TNS) & Japan \\
\hline & Takesako 5597 (VIC, TNS) & Japan \\
\hline $\begin{array}{l}\text { Microlepia izu-peninsulae } \\
\text { Sa.Kurata }\end{array}$ & Nakaike (CRH- 239661) & Japan \\
\hline Microlepia obtusiloba Hayata & Iwatsuki \& Kato 51 (CRH) & Japan \\
\hline \multirow{3}{*}{$\begin{array}{l}\text { Microlepia speluncae (L.) } \\
\text { T.Moore }\end{array}$} & Schwartsburd \& Becari-Viana 3290 (VIC) & Brazil \\
\hline & Schwartsburd \& Becari-Viana 3310 (VIC) & Brazil \\
\hline & Schwartsburd \& Becari-Viana 3315 (VIC) & Brazil \\
\hline
\end{tabular}


Appendix 1: Continued.

\begin{tabular}{lll}
\hline \multicolumn{1}{c}{ Species } & \multicolumn{1}{c}{ Vouchers } & \multicolumn{1}{c}{ Locality } \\
\hline Microlepia strigosa (Thunb.) & Croft 836 (CRH) & Papua New Guinea \\
C.Presl & Braithwaite 2491 (CRH) & New Zealand \\
& Hovell (CRH-465258 A) & New Zealand \\
& Kido 12966 (VIC, TNS) & Japan \\
Oenotrichia maxima (E.Fourn.) & Brownlie 200 (CRH) & New Caledonia \\
Copel. & & \\
Paesia glandulosa (Sw.) Kuhn & Schwartsburd \& Fortuna-Perez 2929 (VIC) & Brazil \\
& Schwartsburd \& Fortuna-Perez 2930 (VIC) & Brazil \\
& Schwartsburd \& Fortuna-Perez 2931 (VIC) & Brazil \\
Paesia rugosula (Labill.) Kuhn & More \& Brownlie 463 (CRH) & New Caledonia \\
Paesia scaberula (A.Rich.) & Smith 84 (CRH) & New Zealand \\
Kuhn & Moore (CRH-533179) & New Zealand \\
Paesia tahitensis Copel. & Sykes 446 (CRH) & French Polynesian \\
Pteridium arachnoideum & Schwartsburd et al. 2838 (VIC, NSW) & Brazil \\
(Kaulf.) Maxon subsp. & Schwartsburd et al. 2837 (VIC) & Brazil \\
arachnoideum & Schwartsburd et al. 3383 & Brazil \\
Pteridium arachnoideum subsp. & Alves da Silva et al. 01 (VIC, NSW). & Brazil \\
campestre (Schrad.) & & \\
Schwartsb. \& P.L.R. Moraes & & \\
\hline
\end{tabular}

